\title{
Analysis on View of Romantic Relationship of "Post- 95" (Born after 1995) College Girls
}

\author{
$\mathrm{Mu} \mathrm{Xu}$ \\ School of Information Science and Engineering \\ Zaozhuang University \\ Zaozhuang, China
}

\author{
Xiaoxia Ge \\ School of Foreign Languages \\ Zaozhuang University \\ Zaozhuang, China
}

\author{
Zhengjie Zhu \\ School of Information Science and Engineering \\ Zaozhuang University \\ Zaozhuang, China
}

\begin{abstract}
As college girls play a special role in romantic relationships, it is significant for the healthy growth of contemporary college girls to have a comprehensive research on the view of romantic relationship of college girls, as well as on how to conduct a psychological guidance for them. In this background, questionnaires are completed by 293 college girls to obtain their opinions on and attitudes toward view of romantic relationship, sexual concept and value in a relationship and to summarize the existing issues on view of romantic relationship of post-95 college girls. It further attempts to discuss approaches of psychological education for girls and to provide a reasonable plan and effective solution to moral education for college students, especially group education for girls.
\end{abstract}

Keywords-college girls; view on romantic relationship; sexual concept; psychological education

\section{INTRODUCTION}

A poem in The Book of Songs goes like this, "The waterfowl would coo, upon an islet in the brooks; a lad would like to woo, a lady with pretty looks." When a lad "woos" a girl, it's because of her "good looks" and also her "being a lady". Both physiological and psychological demands need to be satisfied. Besides, there is also demand for attachment, which is demand for social attribute. Love is a process where the above three basic demands are satisfied simultaneously and where experience is gained. In real life, everyone faces the topic of love and people's views of romantic relationship are affecting everyone's life. Thanks to globalization, speedy circulation of internet information and societal tendency toward understanding and respect in terms of free choice of individuals, post-95 college girls, as active and important "elements" in college, are indecisive among various values. In particular, such issues as universal phenomenon and younger-age trend of romantic relationship of college girls, as well as psychological frustration from romantic relationship, are prominent. Therefore, among college ideological and political educations, group education for college girls is extremely important. It is not only an inevitable requirement of ideological and political education for college students in a new situation but also a realistic demand to improve physical and psychological health of college students clarify the view of romantic relationship of post-95 college girls, to analyze the main existing issues of their view of romantic relationship and the causes, and to propose the effective measures.

\section{STATISTICS AND ANALYSIS ON SURVEY RESUlT}

A random sampling is adopted for this survey. A total of 293 questionnaires were given and 293 were collected, 263 were valid for the $91.5 \%$ response rate. The result of the survey is fairly objective and truthful, and this has laid a good foundation for the following statistical work. Designed by single-choice ones, the questionnaires compose of six parts with a total of 23 questions. The first part is basic status, the second is survey on view of romantic relationship; the third is survey on sexual attitudes; the fourth is survey on view of romantic consumption and the fifth is survey on psychological behavior after break-up.

\section{A. Basic Status of Respondents}

Among the respondents, there are 138 freshman girls, 46 sophomore girls, 50 junior girls and 34 senior girls. $18.52 \%$ of them are students of social science and $81.48 \%$ are students of natural science. 122 of them are from urban families and 146 are from rural families.

\section{B. Survey and Analysis on Status and Motive of Romantic Relationship of Respondents}

According to the survey, among all 268 students, 84 are in a relationship now, accounting for $29.36 \%$ of the total; among them, girls who are having a crush account for $7.34 \%$ of the total respondents. 28 girls are ready to commit to a relationship, accounting for $9.79 \%$ of the total respondents. 161 had been in a romantic relationship, accounting for $56.29 \%$ of the total, while 125 have never been in a relationship, accounting for $43.71 \%$ of the total. It can be 
seen from the survey that 189 of them think it motivates their study and life to have a relationship, accounting for $66.33 \%$ of the total; 57 of them think it distracts energy, wastes time and causes worse scores, accounting for $19.89 \%$ of the total; 22 of them think it isolates them from the group, accounting for $7.65 \%$ of the total respondents; 18 of them think it impacts normal relationship with classmates, accounting for $6.13 \%$ of the total respondents. $48.41 \%$ of them engage in a relationship in order to have a partner for study and life, which represents the ideas of the majority; $14.30 \%$ of them aim at getting married, $17.15 \%$ of them keep the relationship without a plan and $20.14 \%$ of them are uncertain about the relationship.

\section{Survey and Analysis on Romantic Behavior of Respondents}

The survey on premarital sexual behavior indicates that, $14.7 \%$ of the girls find it "disgusting and irresponsible"; $18.53 \%$ of the girls find it "reasonable but not legal"; $35.31 \%$ of the girls find premarital sexual behavior "a normal physical demand"; $31.46 \%$ of the girls think that premarital sexual behavior is negative for physical and mental health of both parties. It can be seen from the survey that, $34.69 \%$ of the girls can accept hand-holding in a relationship; $26.18 \%$ of the girls can accept hugging involved; $21.94 \%$ of the girls can accept kissing in a relationship; girls who think lovers can "touch each other's body" account for $9.17 \%$ of the total; 18 girls can accept lovers living together, accounting for $6.29 \%$ of the total; 5 girls can accept sexual behavior between lovers, accounting for $1.73 \%$ of the total respondents. It can be seen from the survey that, $50 \%$ of the girls think that intimate behavior "is okay as long as others are not impacted"; $26.53 \%$ of the girls think that intimate behavior "is other people's private matter and should not be intervened"; $20.92 \%$ of the girls think that intimate behavior "can be conducted in a secluded space"; only $2.55 \%$ of the girls think it is okay to ignore other people when they are sexually aroused. It can be seen from the survey that, $84.69 \%$ of the girls oppose to heterosexual cohabitation in college and $15.31 \%$ of the girls support heterosexual cohabitation in college. $79.59 \%$ of the girls oppose to premarital cohabitation and $20.41 \%$ of the girls support premarital cohabitation.

\section{Survey and Analysis on Consumption in Romantic Relationship of Respondent}

In the survey on monthly consumption expense in romantic relationship, those whose romantic consumption takes up $30 \%$ to $50 \%$ of the total consumption are 161 respondents, accounting for $56.29 \%$; $15 \%$ to $30 \%$ for 103 respondents, accounting for $36.01 \%$; less than $15 \%$ for 13 respondents, accounting for $4.55 \%$; more than $50 \%$ for 9 respondents, accounting for $3.15 \%$. In terms of the question of "who pays for whom" between boys and girls, "post-95" college girls tend to be independent and open-minded. Among the 286 girl respondents, only 22 think boys should pay for girls. The results of the survey indicate that: $49.49 \%$ of the girls think "they should split the bill for most times and financial status should be separated"; $42.35 \%$ of the girls think "whoever takes the money should pay, two lovers can put their money together for expenses and there is no need to separate their financial status that clearly"; $7.65 \%$ of the girls think "boys should pay for girls primarily"; $0.51 \%$ of the girls think "whoever that comes from a richer family background should pay, disregarding the gender".

\section{E. Analysis on Psychological Behavior after Break-up of a Romantic Relationship of Respondents}

According to the survey, $1.02 \%$ of the girls will start degenerating due to break-up initiated by their counterparts; $1.04 \%$ of the girls will be devastated and even think about committing suicide due to break-up initiated by their counterparts; $50 \%$ of the girls will choose to "have a peaceful break-up"; $56.94 \%$ will feel very sad but selfcontrolled. $56.12 \%$ will still believe in romantic love and be a good friend with their ex-lover after break-up; $34.19 \%$ of the girls express that it's hard to imagine because of their lack of experience. $6.12 \%$ of the girls hated their counterparts and became a stranger to them. $57 \%$ of the girls became dejected, never contacted their counterparts after break-up and would not believe in romantic love again.

After a break-up, girls who express that they will "cherish the one they have" account for $46.43 \%$ of the total respondents; those who express that they will "become afraid of devoting to love" account for $14.29 \%$ of the total respondents; those who express that they "learn to treat romantic love in a sophisticated way" account for $18.88 \%$ of the total respondents; $20.40 \%$ of the girls express that there will be other changes after a break-up.

\section{SUMMARY ON VIEW OF ROMANTIC RELATIONSHIP OF "Post-95" COLLEGE GIRLS}

The views of romantic relationship and marriage of "post-95" college girls are generally healthy and diversified. Most girls long for a romantic relationship in college, for diversified purposes. A rarity of them has impure motives and a negative view on romantic relationship and marriage, and a cynical outlook. In terms of premarital sexual behavior, college girls are more prudent. Consumption behavior in a romantic relationship tends to be rational but irrational consumption exists too, and equality and freedom between genders are emphasized. In the event of break-up, some girls will encounter irrational ideas and behaviors.

\section{ANALYSIS ON CAUSES OF ROMANTIC RELATIONSHIP ISSUES OF COLLEGE GIRLS}

The expectations of female characters in traditional family education have an impact on motive and confidence of college girls to aspire to success, leading contemporary college girls to a relatively disadvantageous position in dealing with emotional issues. This survey analysis indicates that the survey respondent college girls have psychological demand for independence and gender equality. For them to gain recognition and status both in the family and in the society, it requires the college girls to make more efforts.

Internet interaction replaces traditional interaction. With the emergence of social networking websites and such chat 
tools as QQ and Momo, college students are more used to meeting people of opposite sex via internet, and even getting in a romantic relationship and getting married. However, the authenticity of internet information is hard to identify.

At present, there is content related to emotional education in college ideological education. However, generally speaking, the education content is not sufficient and the education approach needs to be improved. It is insufficient for college students to establish a normal view of marriage and romantic relationship. Innovative reform is insufficient too. Moral education for college students shall not only institutional improvement but also psychological education for girls.

\section{GUIDANCE AND SUGgESTION ON VIEW OF MARRIAGE AND ROMANTIC RELATIONSHIP OF "POST-95” COLLEGE STUDENTS}

Based on the above survey results, colleges and universities should take full advantage of entrance education and other lectures to make girls understand romantic relationship and marriage so as to guide college girls to establish a correct view of romantic relationship. First of all, freshman orientations and other lectures should be fully utilized to make girls understand romantic relationship and marriage so as to guide college girls to establish a correct view of romantic relationship. Systematic education on physiological hygiene and sex for girls should be reinforced. Systematic education on physiological hygiene and sex should be implemented so that girls will have a healthy view of sex, as well as the knowledge of "sexual psychology" and "sexual physiology", so that the girls learn about self-respect. Secondly, it is a topic worth colleges' great attention how to establish "one-on-one" psychological consultation "classroom" for girls. In the relatively enclosed "one-onone" environment, it is easier for girls to confide, to untie the knots in their mind and to receive help from teachers. Lastly, with help in setting up their life and study goals for college phase, college girls can improve in dealing with various relationships in love.

\section{CONCLUSION}

Based on the above, college is the most wonderful phase for college students and an important phase when college girls form their view of romantic relationship and marriage. A positive view of romantic relationship and marriage plays a crucial role in a wonderful future life of "post-95" college girls. Growth education should be applied to care about girls, college girls' awareness of self-protection should be enhanced and a mechanism of girl education in correspondence with social development should be striven for and formed, in order for college girls to form a virtuous cycle of love, life and study.

\section{REFERENCES}

[1] Chen Fada, "Exploration and Analysis on Change of View of Romantic Relationship and Marriage of Post-90 College Students",Jorunal of Suzhou Education Institute, April 2016, in press.
[2] Gao Jinchao and Liao Qin, "Status of Female College Students in Love - Taking S University as an example", Journal of Bingtuan Education Institute,January 2016, in press. 